\title{
miR than meets the eye
}

\author{
Julien Sage $e^{1,2,4}$ and Andrea Ventura ${ }^{3,4,5}$ \\ ${ }^{1}$ Department of Pediatrics, Stanford University, Stanford, California 94305, USA; ${ }^{2}$ Department of Genetics, Stanford University, \\ Stanford, California 94305, USA; ${ }^{3}$ Cancer Biology and Genetics Program, Memorial Sloan Kettering Cancer Center, New York, \\ New York 10065, USA
}

Retinoblastoma is a rare pediatric cancer that has served as a paradigm to investigate the mechanisms of tumorigenesis. In this issue of Genes \& Development, Conkrite and colleagues (pp. 1734-1745) found high levels of the miR17 92 and miR-106b-25 microRNAs in primary retinoblastomas and show that overexpression of $\mathrm{miR}-17$ 92 accelerates retinoblastoma development in mice by promoting proliferation, in part by reducing expression of the cell cycle inhibitor p21. These experiments identify the $R B / m i R-17 \sim 92 / p 21$ axis as a critical regulator of retinoblastoma tumorigenesis and potentially many other cancers.

\section{miRNAs and cancer}

One of the most exciting new developments of the past two decades has been the identification of microRNAs (miRNAs) and the realization that these small, noncoding RNAs provide an additional layer of complexity in the regulation of gene expression (Bartel 2009). It is estimated that more than one-third of human protein-coding genes are subjected to regulation by miRNAs. Given their widespread effect on gene expression, it is therefore not surprising that miRNAs play key roles in mammalian development and in diseases. In fact, deregulated expression of miRNAs is a common feature of human cancers, and individual miRNAs acting as bona fide oncogenes or tumor suppressors have been described (Ventura and Jacks 2009).

Among the oncogenic miRNAs, the $m i R-17 \sim 92$ cluster, also known as OncomiR-1, is the subject of intense investigation. Recurrent focal amplifications of the $m i R-17 \sim 92$ locus have been reported in a significant fraction of diffuse large B-cell lymphomas (Ota et al. 2004), and overexpression of the six miRNAs encoded by this cluster is observed in a wide variety of solid and liquid tumors (for review, see Olive et al. 2010). Furthermore, experiments in mice have provided conclusive evidence that $m i R-17 \sim 92$ is a bona fide oncogene in lymphoma (He et al. 2005; Mu et al. 2009; Olive et al. 2009), colon cancer (Dews et al. 2006), and medulloblastoma (Uziel et al. 2009).

[Keywords: retinoblastoma; $\mathrm{Rb}$; retina; microRNA; cancer; miR-17 92]

${ }^{4}$ These authors contributed equally to this work.

${ }^{5}$ Corresponding author.

E-mail venturaa@mskcc.org

Article is online at http://www.genesdev.org/cgi/doi/10.1101/gad.17454011.
The miR-17 92 cluster belongs to a highly conserved family of polycistronic miRNA genes, whose two other members are the $m i R-106 a \sim 363$ cluster and the $m i R$ $106 b \sim 25$ cluster. Collectively, these three loci encode for 15 miRNAs that can be further grouped into four distinct "seed" families based on sequence similarity (Fig. 1A,B). Gene targeting experiments in mice have shown that miR-17 92 is essential for mammalian development, and that the three clusters share partially overlapping targets and functions (Ventura et al. 2008). Nevertheless, relatively little is known about the relative contribution of the various miRNAs encoded by the three clusters.

\section{Retinoblastoma in humans and mice}

In this issue of Genes \& Development, Conkrite et al. (2011) provide compelling evidence implicating $m i R$ 17 92 and $m i R-106 b \sim 25$ in the pathogenesis of retinoblastoma, a cancer of the eye that occurs only in young children. Although retinoblastoma is a rare cancer (approximately one out of 20,000 births), its study has contributed tremendously to our understanding of cancer in general. In fact, the first tumor suppressor gene, $R B$, was identified from retinoblastoma patients, and it is now clear that most human cancers harbor mutations in $R B$ itself or in various components of the RB pathway. Importantly, retinoblastoma, whose initiating event is known, provides a simple but powerful system to study cooperating events in tumorigenesis. Thus, studying retinoblastoma development may teach us how most human cancers initiate and progress (for a recent review, see Chinnam and Goodrich 2011).

Retinoblastoma development seems specific to humans. Spontaneous retinoblastomas have never been observed in rodents, and only a handful of cases have been reported in mammals other than humans (Syed et al. 1997; Fugaro et al. 2005; Knottenbelt et al. 2007). Accordingly, targeted deletion of both $R b$ alleles in a variety of mouse retinal cells at different stages of retinal development does not lead to the development of eye tumors, but merely results in ectopic proliferation and increased cell death (Chen et al. 2004; MacPherson et al. 2004; Zhang et al. 2004).

In mammals, RB belongs to a family of structurally and functionally related proteins including RB itself, as well as p107 and p130. The three family members are inhibited by the same Cyclin/cyclin-dependent kinase (CDK) complexes; interact with a number of identical partners, including viral 


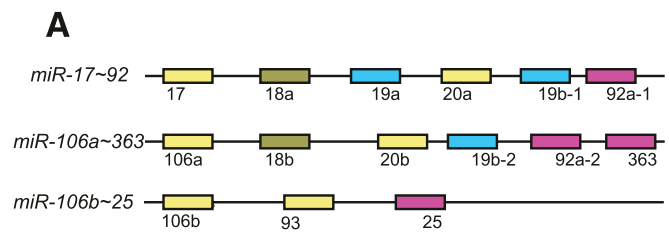

B
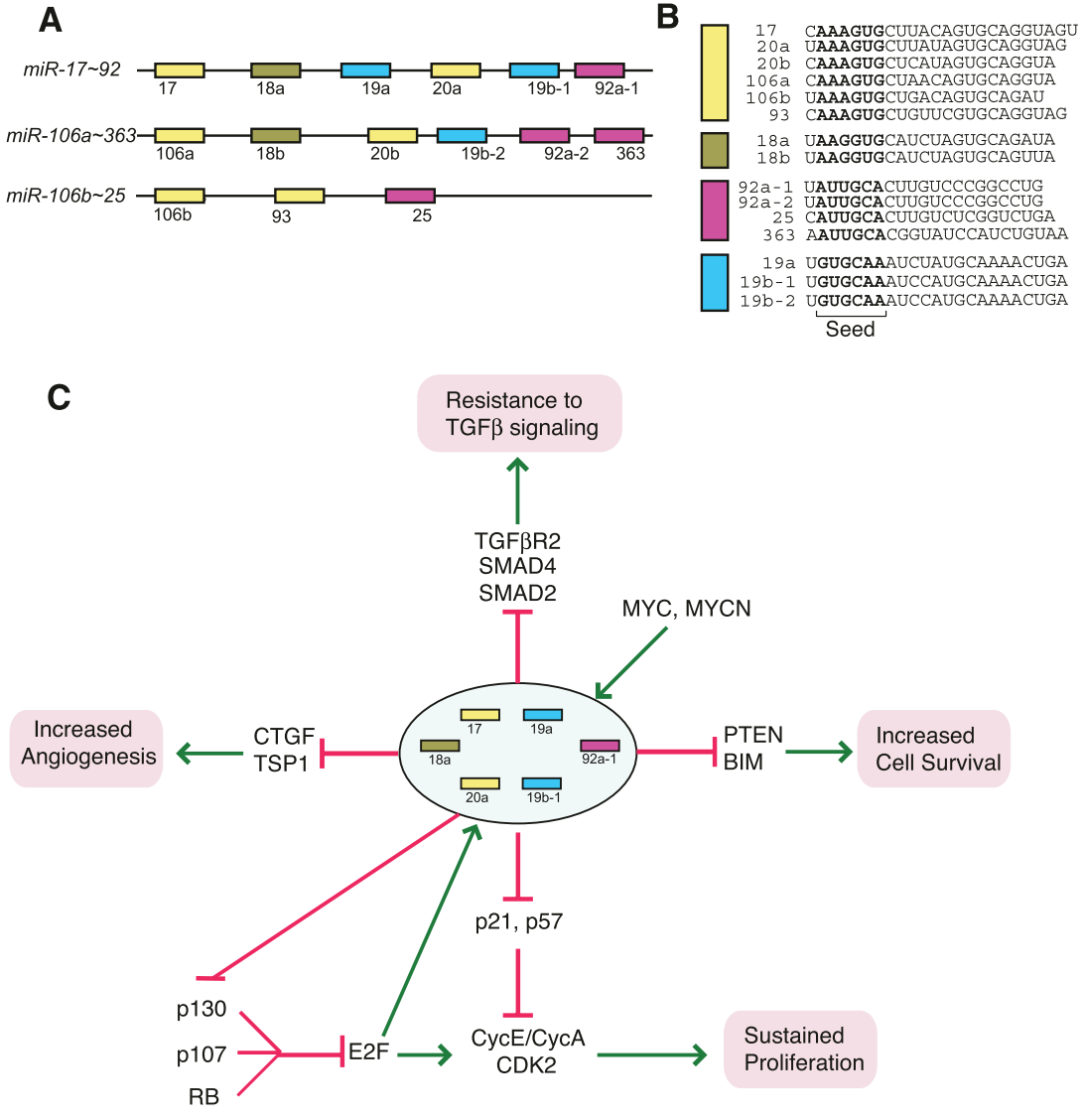

Figure 1. (A) Schematic representation of the $m i R-17 \sim 92$ cluster and its two paralogs, miR$106 a \sim 363$ and miR-106b 25. (B) The 15 miRNAs encoded by these three polycistronic miRNA clusters are shown and grouped based on their "seed" sequence. miRNAs belonging to the same "seed" group are predicted to target largely overlapping sets of genes. $(C)$ Schematic of the many oncogenic activities attributed to $m i R-17 \sim 92$, with special emphasis on its role as a modulator of cell proliferation. For simplicity, only a subset of interactions is shown. Conkrite et al. (2011) identify the miR-17 92 miRNA as a novel downstream mediator of RB function. miR17 92 expression may be induced by E2F, by members of the MYC family, or due to genomic amplification. In retinoblastoma cells and possibly in other RB mutant cells, miR-17 92 is thought to promote cancer in part by inhibiting the expression of cell cycle inhibitors, including $\mathrm{p} 21$, feeding back onto the RB pathway. oncoproteins, E2F transcription factors, and chromatin remodeling enzymes; and control cell cycle progression (for review, see Levine 2009; Chinnam and Goodrich 2011). Analysis of mice with combinations of mutations in $R b$ family genes has provided evidence for strong overlapping functions within the $\mathrm{RB}$ family. First, $p 130^{-/-} ; p 107^{-/-}$ mice die just after birth with differentiation defects in bones and abnormalities in chondrocyte proliferation, while deletion of $p 107$ or $p 130$ had no developmental consequences in the same genetic background (Cobrinik et al. 1996). In addition, $\mathrm{Rb}^{-/-} ; \mathrm{p} 107^{-/-}, \mathrm{Rb}^{-/-} ; \mathrm{p} 130^{-/-}$, and $R b^{-/-} ; p 107^{-1-} ; p 130^{-/-}$embryos die earlier during mouse development than $R b^{-/-}$embryos, with more pronounced developmental defects, including increased cell death and abnormal proliferation (Lee et al. 1996; Berman et al. 2009; Wirt et al. 2010).

Based on these observations, several groups generated mice with mutations in $R b$ and $p 107$ or $R b$ and $p 130$ in the developing retina. These double-knockout mice develop tumors that strongly resemble human retinoblastomas, including in their metastatic potential, thereby providing a novel system in which to study retinoblastoma in vivo and ex vivo (for review, see MacPherson 2008). The tumor suppressor function of p107 and p130 in $R b$ mutant cells has been extended to several other organs and tissues (for recent examples, see Jiang et al. 2010; Schaffer et al. 2010). One caveat of these mouse models of retinoblastoma is that they rely on the inactivation of two genes instead of just one, as occurs in patients. Nevertheless, the availability of these $R b / p 107$ and $R b / p 130$ mutant mouse models, coupled with the capacity to compare the mouse tumors with human primary retinoblastomas, has provided powerful means to investigate molecular and cellular events in the genesis of these tumors.

\section{A role for miRNAs in retinoblastoma development}

To identify additional events that cooperate with RB loss in retinoblastoma development, Conkrite et al. (2011) performed array comparative genomic hybridization (CGH) on a panel of 21 murine retinoblastomas generated by the concomitant inactivation of $R b$ and $p 107$. In two tumors they observed focal amplification of a chromosomal region containing the $m i R-17 \sim 92$ cluster. To extend this finding, they examined a panel of 32 human primary retinoblastomas samples, showing increased miR-17 92 copy number in two of them. Interestingly, when they looked for miR-17 92 expression levels in human and murine primary retinoblastomas and retinoblastoma cell lines, Conkrite et al. (2011) found that it correlated well with copy number in murine samples, while in human samples the six miRNAs encoded by this cluster were expressed at very high levels, irrespective of $m i R-17 \sim 92$ copy number. Although this finding needs to be confirmed in a larger set of retinoblastomas, it suggests that in human retinoblastomas, up-regulation of $\mathrm{miR}-17 \sim 92$ is a common event 
that is usually achieved via transcriptional or post-transcriptional mechanisms. E2F activity is high in RB mutant cells such as retinoblastoma cells; in addition, the MYC oncogene is activated in a fraction of mouse and human retinoblastomas (Lee et al. 1984; MacPherson et al. 2007). Because $m i R-17 \sim 92$ is a direct transcriptional target of both MYC and E2F1 (O'Donnell et al. 2005; Sylvestre et al. 2007; Woods et al. 2007), the activation of these two oncogenic transcription factors may partially explain the upregulation of $\mathrm{miR}-17 \sim 92$ levels in retinoblastoma cells.

Correlation is not proof of causation. Hence, Conkrite et al. (2011) used a transgenic approach to determine whether increased expression of $m i R-17 \sim 92$ could play a role in the genesis of retinoblastoma. Overexpression of miR-17 92 per se did not cause any detectable defect in retinal development, nor was it sufficient to induce tumor formation. However, in the absence of $R b$ and $p 107$, it produced a dramatic acceleration of retinoblastoma formation, resulting in highly aggressive bilateral tumors. Unfortunately, $m i R-17 \sim 92$ overexpression in the context of $R b$ loss alone was not sufficient to induce tumors in mice. Thus, while these results clearly implicate $m i R-17 \sim 92$ in the pathogenesis of retinoblastoma, they do not explain why the simultaneous loss of $R b$ and $p 107$ is required in mice but not in humans.

A particularly interesting aspect of the new data presented by Conkrite et al. (2011) is that they provide new mechanistic insights into the oncogenic activity of $m i R$ 17 92. Experiments performed in mouse models had previously shown that $m i R-17 \sim 92$ can accelerate tumorigenesis by suppressing apoptosis (Mu et al. 2009; Olive et al. 2009; Mavrakis et al. 2010), by increasing angiogenesis (Dews et al. 2006), or by suppressing TGF- $\beta$ signaling (Mestdagh et al. 2010). Conkrite et al. (2011) now show that in retinoblastomas, the main consequence of $m i R-17 \sim 92$ overexpression is an increase in cell proliferation, at least in part via direct inhibition of key cell cycle inhibitors such as $\mathrm{p} 21^{\mathrm{CIP} 1}$ and $\mathrm{p} 57^{\mathrm{KIP} 2}$. Furthermore, by performing experiments in retinoblastoma cell lines, they show that this proliferative activity is not due to $m i R-19 a$ and $m i R-19 b$, but to $m i R-17$ and $m i R-20 a$, two other members of the cluster. While the ability of these miRNAs to repress cell cycle inhibitors had been previously reported (Fontana et al. 2008; Ivanovska et al. 2008; Sengupta et al. 2008), Conkrite et al. (2011) demonstrate their functional relevance in vivo.

As is often the case with new findings, the work of Conkrite et al. (2011) raises several interesting questions for future research. For example, it will be important to determine whether endogenous $m i R-17 \sim 92$ is required for retinoblastoma formation. This could have therapeutic implications, as Conkrite et al. (2011) show that genetic inactivation of $m i R-17 \sim 92$ does not interfere with retinal development. Thus, inhibiting these miRNAs in the eyes of young children, at a time when their retinas are still developing, might be a viable strategy to slow or prevent retinoblastoma growth without major side effects.

One of the challenges in the field in the next few years will be to continue to identify key determinants of retinoblastoma development. In particular, one prediction from the observation that $R b / p 107$ and $R b / p 130$ mutant mice develop retinoblastoma is that $R b$ deletion might also cooperate with loss of other cell cycle inhibitors such as members of the p16 and p21 families of cell cycle inhibitors. In support of this idea, Conkrite et al. (2011) show that genetic inactivation of $p 21^{\text {Cip } 1}$ in $R b / p 107$ mutant retinas leads to increased proliferation at postnatal day 22; it will be interesting to determine whether it also results in accelerated tumorigenesis.

Finally, it will be important to investigate the role of the $m i R-17 \sim 92$ paralogs $m i R-106 a \sim 363$ and $m i R-106 b \sim 25$ in retinoblastoma formation. These two clusters contain miRNAs that are virtually identical to those encoded by miR-17 92 (Fig. 1A,B) and synergize with miR-17 92 in modulating embryonic development (Ventura et al. 2008). It is thus plausible that their deregulation may also contribute to retinoblastoma development. Consistent with this hypothesis, Conkrite et al. (2011) detected copy number increase in the region containing miR-106b 25 in one murine and four human retinoblastomas, although the functional consequences of these alterations were not investigated further.

\section{Regulatory networks downstream from $\mathrm{RB}$ in cancer}

In the last two decades, a number of positive and negative feedback mechanisms have been identified in cells following loss of RB function. For instance, loss of RB function results in activation of E2F transcription factors and upregulation of $p 107$ transcription, which is thought to largely explain why p107 can compensate for loss of RB in many contexts, including in the mouse retina (Burkhart et al. 2010 and references therein). Interestingly, one reason why patients mutant for $R B$ develop retinoblastoma even in the presence of a wild-type $p 107$ gene might be because loss of RB does not up-regulate $p 107$ in embryonic retinal progenitors (Donovan et al. 2006). Other classical E2F targets whose up-regulation slows cell cycle progression include the cell cycle inhibitors p19 ${ }^{\mathrm{ARF}}$ (Aslanian et al. 2004) and p21 (Hiyama et al. 1998). In contrast, activation of E2F in RB mutant cells also prevents cell death by increasing the expression of the p53 deacetylase Sirt1 (Chen et al. 2009) and promotes cell cycle progression by increasing the expression of the cell cycle machinery, including E2F1 itself, Cyclin E, and Cyclin A (for review, see Chinnam and Goodrich 2011). Independently of E2F, loss of RB can also lead to decreased levels of the cell cycle inhibitor p27 (Binne et al. 2007). A truly interesting aspect of the new data presented by Conkrite et al. (2011) is that they identify miR-17 92 as a central node in the regulatory networks centered on RB in the control of the G1/S transition (Fig. 1C). As mentioned above, miR-17 92 has been shown to be a direct transcriptional target of E2F transcription factors (Sylvestre et al. 2007; Woods et al. 2007), which provides a direct link between the canonical $\mathrm{RB}$ pathway and this miRNA.

In conclusion, the new data presented by Conkrite et al. (2011) not only provide novel insights into the pathogenesis of retinoblastoma, but also add to the growing list of human cancers in which the miR-17 92 cluster plays 
a key role. Importantly, these data also show that the mode of action of $m i R-17 \sim 92$ is highly context-specific, with different members of the cluster acting as the key oncogenic determinant in different tumor types. If, as seems highly plausible, a role for $m i R-17 \sim 92$ is confirmed in a broad range of RB mutant tumors, the pharmacologic inhibition of this cluster may have therapeutic potential in a very large group of cancer patients.

\section{Acknowledgments}

We thank Ursula Ehmer and Jennifer Hollenstein for helpful discussions on the manuscript. We apologize to our colleagues whose work was not cited due to space limitations. The work in J.S.'s laboratory on RB is supported by $\mathrm{NIH} / \mathrm{NCI}$ grant R01 CA114102-01A1 and CIRM grant RB1-01385. The work in A.V.'s laboratory is supported by a NIH/NCI grant R01CA149707, by the Sidney Kimmel Foundation, and by the Geoffrey Beene Cancer Research Foundation.

\section{References}

Aslanian A, Iaquinta PJ, Verona R, Lees JA. 2004. Repression of the Arf tumor suppressor by E2F3 is required for normal cell cycle kinetics. Genes Dev 18: 1413-1422.

Bartel DP. 2009. MicroRNAs: target recognition and regulatory functions. Cell 136: 215-233.

Berman SD, West JC, Danielian PS, Caron AM, Stone JR, Lees JA. 2009. Mutation of p107 exacerbates the consequences of $\mathrm{Rb}$ loss in embryonic tissues and causes cardiac and blood vessel defects. Proc Natl Acad Sci 106: 14932-14936.

Binne UK, Classon MK, Dick FA, Wei W, Rape M, Kaelin WG Jr, Naar AM, Dyson NJ. 2007. Retinoblastoma protein and anaphase-promoting complex physically interact and functionally cooperate during cell-cycle exit. Nat Cell Biol 9: 225-232.

Burkhart DL, Wirt SE, Zmoos AF, Kareta MS, Sage J. 2010. Tandem E2F binding sites in the promoter of the p107 cell cycle regulator control p107 expression and its cellular functions. PLoS Genet 6: e1001003. doi: 10.1371/journal.pgen.1001003.

Chen D, Livne-Bar I, Vanderluit JL, Slack RS, Agochiya M, Bremner R. 2004. Cell-specific effects of RB or RB/p107 loss on retinal development implicate an intrinsically deathresistant cell-of-origin in retinoblastoma. Cancer Cell 5: 539-551.

Chen D, Pacal M, Wenzel P, Knoepfler PS, Leone G, Bremner R. 2009. Division and apoptosis of E2f-deficient retinal progenitors. Nature 462: 925-929.

Chinnam M, Goodrich DW. 2011. RB1, development, and cancer. Curr Top Dev Biol 94: 129-169.

Cobrinik D, Lee MH, Hannon G, Mulligan G, Bronson RT, Dyson N, Harlow E, Beach D, Weinberg RA, Jacks T. 1996. Shared role of the pRB-related p130 and p107 proteins in limb development. Genes Dev 10: 1633-1644.

Conkrite K, Sundby M, Mukai S, Thomson JM, Mu D, Hammond SM, MacPherson D. 2011. miR-17 92 cooperates with $R B$ pathway mutations to promote retinoblastoma. Genes Dev (this issue). doi: 10.1101/gad.17027411.

Dews M, Homayouni A, Yu D, Murphy D, Sevignani C, Wentzel E, Furth EE, Lee WM, Enders GH, Mendell JT, et al. 2006. Augmentation of tumor angiogenesis by a Myc-activated microRNA cluster. Nat Genet 38: 1060-1065.

Donovan SL, Schweers B, Martins R, Johnson D, Dyer MA. 2006. Compensation by tumor suppressor genes during retinal development in mice and humans. BMC Biol 4: 14. doi: 10.1186/ 1741-7007-4-14.
Fontana L, Fiori ME, Albini S, Cifaldi L, Giovinazzi S, Forloni M, Boldrini R, Donfrancesco A, Federici V, Giacomini P, et al. 2008. Antagomir-17-5p abolishes the growth of therapyresistant neuroblastoma through p21 and BIM. PLOS ONE 3: e2236. doi: 10.1371/journal.pone.0002236.

Fugaro MN, Kiupel M, Montiani-Ferreira F, Hawkins JF, Janovitz EB. 2005. Retinoblastoma in the eye of a llama (Llama glama). Vet Ophthalmol 8: 287-290.

He L, Thomson JM, Hemann MT, Hernando-Monge E, Mu D, Goodson S, Powers S, Cordon-Cardo C, Lowe SW, Hannon G), et al. 2005. A microRNA polycistron as a potential human oncogene. Nature 435: 828-833.

Hiyama H, Iavarone A, Reeves SA. 1998. Regulation of the cdk inhibitor p21 gene during cell cycle progression is under the control of the transcription factor E2F. Oncogene 16: 15131523.

Ivanovska I, Ball AS, Diaz RL, Magnus JF, Kibukawa M, Schelter JM, Kobayashi SV, Lim L, Burchard J, Jackson AL, et al. 2008. MicroRNAs in the miR-106b family regulate p21/CDKN1A and promote cell cycle progression. Mol Cell Biol 28: 21672174.

Jiang Z, Deng $\mathrm{T}$, Jones R, Li H, Herschkowitz JI, Liu JC, Weigman VJ, Tsao MS, Lane TF, Perou CM, et al. 2010. Rb deletion in mouse mammary progenitors induces luminal-B or basal-like/EMT tumor subtypes depending on p53 status. J Clin Invest 120: 3296-3309.

Knottenbelt DC, Hetzel U, Roberts V. 2007. Primary intraocular primitive neuroectodermal tumor (retinoblastoma) causing unilateral blindness in a gelding. Vet Ophthalmol 10: 348-356.

Lee WH, Murphree AL, Benedict WF. 1984. Expression and amplification of the N-myc gene in primary retinoblastoma. Nature 309: 458-460.

Lee MH, Williams BO, Mulligan G, Mukai S, Bronson RT, Dyson N, Harlow E, Jacks T. 1996. Targeted disruption of p107: functional overlap between p107 and Rb. Genes Dev 10: $1621-1632$.

Levine AJ. 2009. The common mechanisms of transformation by the small DNA tumor viruses: the inactivation of tumor suppressor gene products: p53. Virology 384: 285-293.

MacPherson D. 2008. Insights from mouse models into human retinoblastoma. Cell Div 3: 9. doi: 10.1186/1747-1028-3-9.

MacPherson D, Sage J, Kim T, Ho D, McLaughlin ME, Jacks T. 2004. Cell type-specific effects of Rb deletion in the murine retina. Genes Dev 18: 1681-1694.

MacPherson D, Conkrite K, Tam M, Mukai S, Mu D, Jacks T. 2007. Murine bilateral retinoblastoma exhibiting rapid-onset, metastatic progression and $\mathrm{N}$-myc gene amplification. EMBO J 26: 784-794.

Mavrakis KJ, Wolfe AL, Oricchio E, Palomero T, de Keersmaecker K, McJunkin K, Zuber J, James T, Khan AA, Leslie CS, et al. 2010. Genome-wide RNA-mediated interference screen identifies miR-19 targets in Notch-induced T-cell acute lymphoblastic leukaemia. Nat Cell Biol 12: 372-379.

Mestdagh P, Bostrom AK, Impens F, Fredlund E, Van Peer G, De Antonellis P, von Stedingk K, Ghesquiere B, Schulte S, Dews $\mathrm{M}$, et al. 2010. The miR-17-92 microRNA cluster regulates multiple components of the TGF- $\beta$ pathway in neuroblastoma. Mol Cell 40: 762-773.

Mu P, Han YC, Betel D, Yao E, Squatrito M, Ogrodowski P, de Stanchina E, D'Andrea A, Sander C, Ventura A. 2009. Genetic dissection of the miR-17 92 cluster of microRNAs in Myc-induced B-cell lymphomas. Genes Dev 23: 28062811.

O'Donnell KA, Wentzel EA, Zeller KI, Dang CV, Mendell JT. 2005. c-Myc-regulated microRNAs modulate E2F1 expression. Nature 435: 839-843. 
Olive V, Bennett MJ, Walker JC, Ma C, Jiang I, Cordon-Cardo C, Li QJ, Lowe SW, Hannon GJ, He L. 2009. miR-19 is a key oncogenic component of mir-17-92. Genes Dev 23: 2839-2849.

Olive V, Jiang I, He L. 2010. mir-17-92, a cluster of miRNAs in the midst of the cancer network. Int J Biochem Cell Biol 42: $1348-1354$.

Ota A, Tagawa H, Karnan S, Tsuzuki S, Karpas A, Kira S, Yoshida Y, Seto M. 2004. Identification and characterization of a novel gene, C13orf25, as a target for 13q31-q32 amplification in malignant lymphoma. Cancer Res 64: 3087-3095.

Schaffer BE, Park KS, Yiu G, Conklin JF, Lin C, Burkhart DL, Karnezis AN, Sweet-Cordero EA, Sage J. 2010. Loss of p130 accelerates tumor development in a mouse model for human small-cell lung carcinoma. Cancer Res 70: 3877-3883.

Sengupta S, den Boon JA, Chen IH, Newton MA, Stanhope SA, Cheng YJ, Chen CJ, Hildesheim A, Sugden B, Ahlquist P. 2008. MicroRNA 29c is down-regulated in nasopharyngeal carcinomas, up-regulating mRNAs encoding extracellular matrix proteins. Proc Natl Acad Sci 105: 5874-5878.

Syed NA, Nork TM, Poulsen GL, Riis RC, George C, Albert DM. 1997. Retinoblastoma in a dog. Arch Ophthalmol 115: 758-763.

Sylvestre Y, De Guire V, Querido E, Mukhopadhyay UK, Bourdeau V, Major F, Ferbeyre G, Chartrand P. 2007. An E2F/miR-20a autoregulatory feedback loop. J Biol Chem 282: $2135-2143$.

Uziel T, Karginov FV, Xie S, Parker JS, Wang YD, Gajiar A, He L, Ellison D, Gilbertson RJ, Hannon G, et al. 2009. The miR17 92 cluster collaborates with the Sonic Hedgehog pathway in medulloblastoma. Proc Nat1 Acad Sci 106: 2812-2817.

Ventura A, Jacks T. 2009. MicroRNAs and cancer: short RNAs go a long way. Cell 136: 586-591.

Ventura A, Young AG, Winslow MM, Lintault L, Meissner A, Erkeland SJ, Newman J, Bronson RT, Crowley D, Stone JR, et al. 2008. Targeted deletion reveals essential and overlapping functions of the miR-17 through 92 family of miRNA clusters. Cell 132: 875-886.

Wirt SE, Adler AS, Gebala V, Weimann JM, Schaffer BE, Saddic LA, Viatour P, Vogel H, Chang HY, Meissner A, et al. 2010. $\mathrm{G} 1$ arrest and differentiation can occur independently of $\mathrm{Rb}$ family function. J Cell Biol 191: 809-825.

Woods K, Thomson JM, Hammond SM. 2007. Direct regulation of an oncogenic micro-RNA cluster by E2F transcription factors. J Biol Chem 282: 2130-2134.

Zhang J, Gray J, Wu L, Leone G, Rowan S, Cepko CL, Zhu X, Craft CM, Dyer MA. 2004. Rb regulates proliferation and rod photoreceptor development in the mouse retina. Nat Genet 36: $351-360$. 


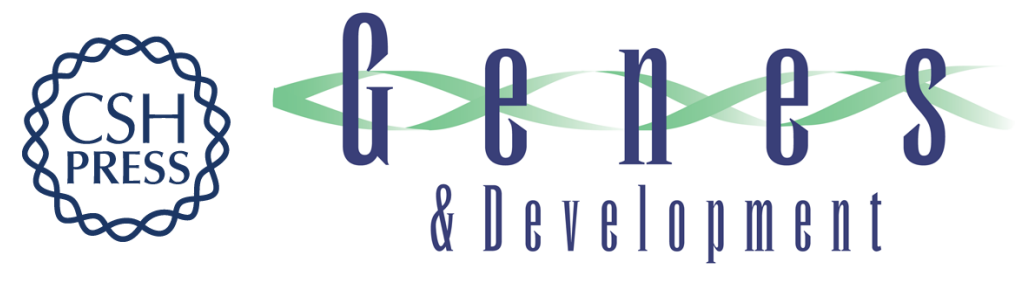

\section{miR than meets the eye}

Julien Sage and Andrea Ventura

Genes Dev. 2011, 25:

Access the most recent version at doi:10.1101/gad.17454011

\section{Related Content}

References

\section{License}

Email Alerting

Service
This article cites 41 articles, 15 of which can be accessed free at: http://genesdev.cshlp.org/content/25/16/1663.full.html\#ref-list-1

Articles cited in:

http://genesdev.cshlp.org/content/25/16/1663.full.html\#related-urls

miR-17<92 cooperates with RB pathway mutations to promote retinoblastoma

Karina Conkrite, Maggie Sundby, Shizuo Mukai, et al.

Genes Dev. August , 2011 25: 1734-1745

Receive free email alerts when new articles cite this article - sign up in the box at the top right corner of the article or click here.

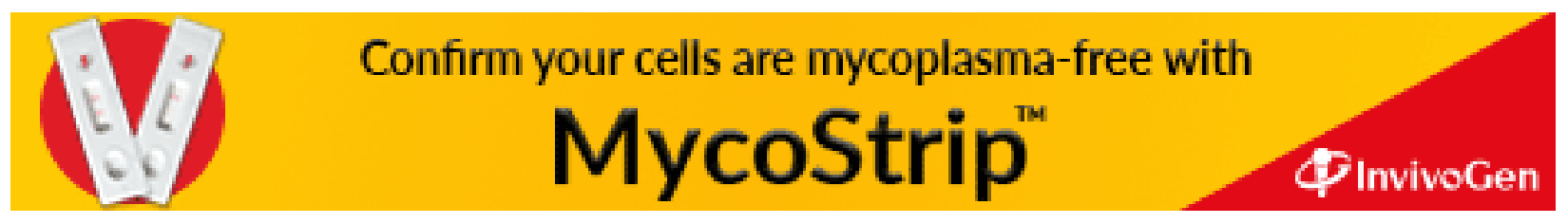

